\title{
Preservation of a certain motoneurone group of the sacral cord in amyotrophic lateral sclerosis : its clinical significance
}

\author{
TORU MANNEN, MAKOTO IWATA, YASUO TOYOKURA, AND \\ KAZUO NAGASHIMA
}

From the Department of Neurology, Institute of Brain Research, and the Department of Pathology, Faculty of Medicine, University of Tokyo, Tokyo, Japan

SUMMARY Histopathological description of a special nerve cell group of the sacral spinal cord in five cases of amyotrophic lateral sclerosis is presented. Remarkable preservation of this group of neurones (the X group of Onuf) was noted in each case, and this is discussed with particular reference to vesicorectal function, since it is well known that the function of bladder and rectal sphincters is often intact until the latest stage of the illness.

In amyotrophic lateral sclerosis, a disease with widespread involvement of striated muscles, the eye muscles and the sphincter muscles of bladder and rectum are characteristically spared until the latest stage of the illness. Although this is one of the most remarkable clinical characteristics of the disease, very few pathological studies have been made to substantiate the finding. This paper describes pathoanatomical findings in the spinal cord in five cases of amyotrophic lateral sclerosis, paying particular attention to the sacral cord.

\section{Cases and methods}

The spinal cord was examined in five necropsied cases of amyotrophic lateral sclerosis. The Table shows the age, sex, main clinical features, and duration of disease in each patient. All the cases showed typical symptoms of lower motor neurone lesions. The spinal cord was fixed in formalin and the sacral part was cut into five segments and embedded in paraffin. Each of the five segments was sectioned serially at a thickness of $15 \mu \mathrm{m}$ and stained with Klüver-Barrera stain. Some sections were also studied with $\mathrm{H}$ and $\mathrm{E}$ and Nissl stains.

The sacral spinal cords, were obtained from four necropsied cases of comparable age and with no neurological symptoms to act as controls. In both

This work was supported by a grant for scientific research from the Ministry of Education of Japan.

Accepted 15 November 1976
Table Details of five cases of amyotrophic lateral sclerosis

\begin{tabular}{llllll}
\hline Case & $\begin{array}{c}\text { Age } \\
(y r)\end{array}$ & Sex & Initial symptoms & \multicolumn{1}{c}{$\begin{array}{l}\text { Duration } \\
\text { of disease } \\
(y r)\end{array}$} \\
\hline 1 & KF & 62 & M & $\begin{array}{l}\text { Muscular atrophy of right } \\
\text { upper extremity }\end{array}$ & 4 \\
2 & YK & 49 & F & $\begin{array}{l}\text { Muscular atrophy of right } \\
\text { upper extremity }\end{array}$ & 9 \\
3 & NO & 68 & F & $\begin{array}{l}\text { Weakness of legs } \\
\text { Weakness and muscular }\end{array}$ & 1.5 \\
4 & YT & 65 & F & $\begin{array}{l}\text { atrophy of legs } \\
\text { Muscular atrophy of upper } \\
\text { extremities }\end{array}$ & 5 \\
5 & ST & 63 & M & &
\end{tabular}

groups, sections of the cord at the cervical, thoracic, and lumbar levels were stained similarly for comparison.

Results

ANTERIOR HORNS OF THE SACRAL CORD

In the cases of amyotrophic lateral sclerosis, there was a severe loss of large motoneurones in both medial and lateral parts of the anterior horns. This was found throughout the sacral segments of the cord, and also at the other cord levels. A few scattered neurones remained, but they never formed a distinct group (Fig. 1). However, a cluster of very well-preserved neurones was observed in the most medial portion of the ventrolateral cell groups of the anterior horn. This group was readily shown by the Klüver-Barrera stain on account of its pale staining background 


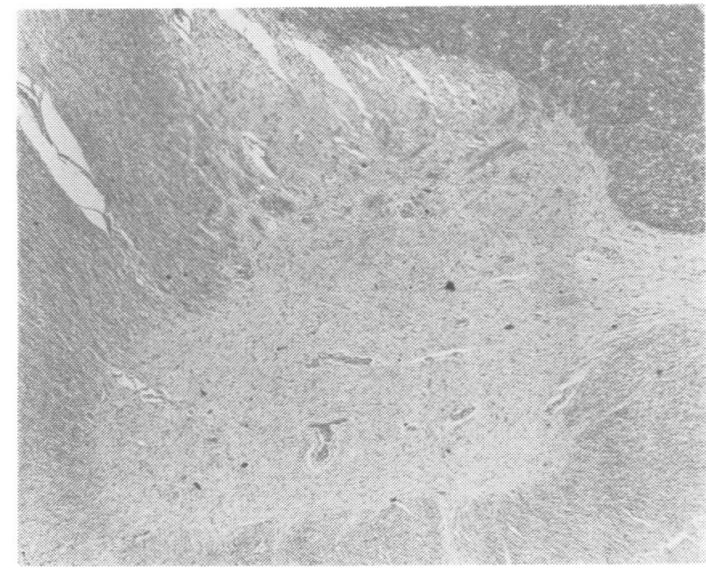

Fig. 1 S 1. Severe degeneration of the anterior horn cells. (Amyotrophic lateral sclerosis, case 2.)

Klüver-Barrera stain.

which was sharply demarcated from the surrounding network of fine myelinated fibres (Fig. 2). Examination of serial sections revealed that this cell group was confined within the second sacral segment between the most rostral and the most caudal margins. The neurones in this cell group were medium in size, their nuclei usually being located in the centre of the cell body. Their Nissl granules were densely and evenly distributed throughout the cell body. The number of neurones belonging to this cell group varied considerably in each serial section, ranging from five to 15 with an average of 10 (Fig. 3a, b).

These findings in the second sacral segment were verified in all cases of amyotrophic lateral sclerosis which we examined; this cell group showed identical findings in controls (Fig. 4a, b).

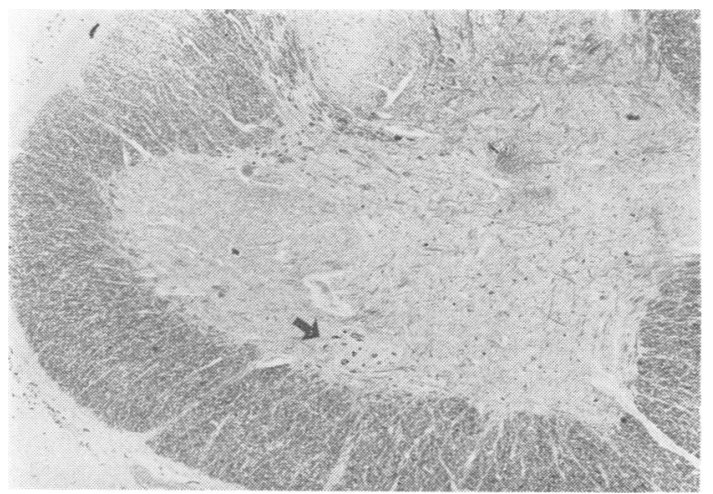

Fig. $2 S$ 2. Group $X$ (Onuf) is well-preserved (arrow). (Amyotrophic lateral sclerosis, case 2.) Klïver-Barrera stain.

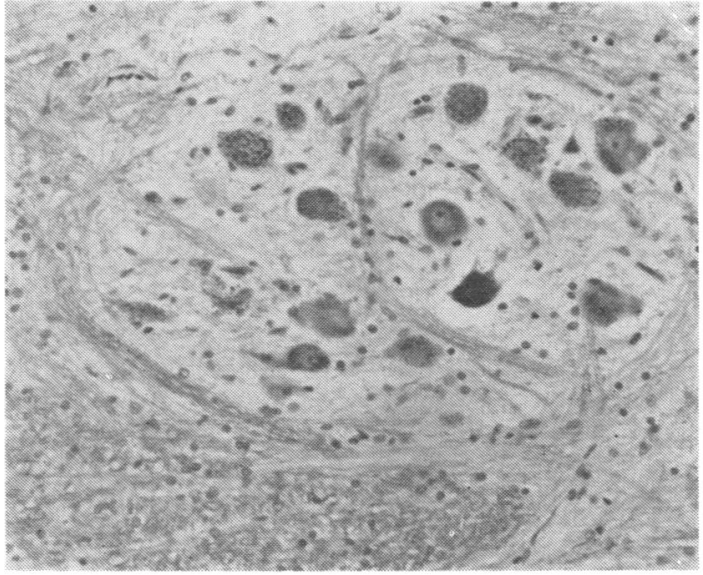

(a)

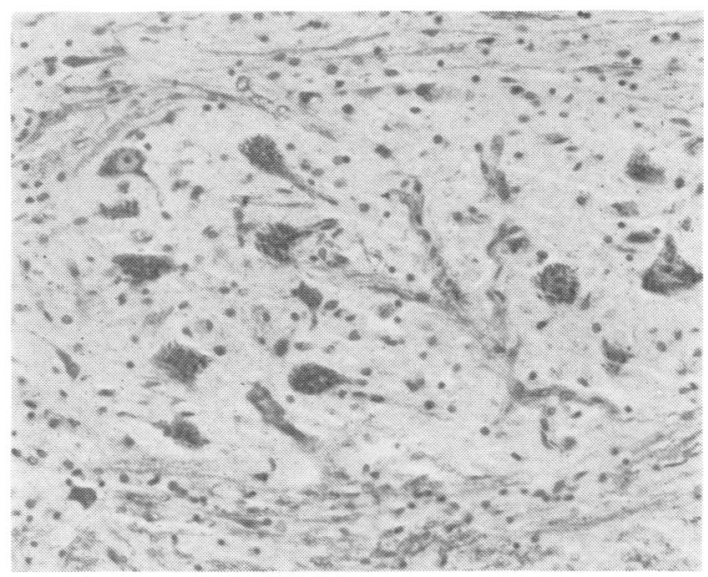

(b)

Fig. 3 Group $X$ in amyotrophic lateral sclerosis is well-preserved and quite indistinguishable from normal case. Klïver-Barrera stain.

(a) Normal. (b) Amyotrophic lateral sclerosis (case 5).

INTERMEDIOLATERAL NUCLEUS OF THE SACRAL CORD The intermediolateral nucleus was found from the second to the fifth segment of the sacral cord inclusive. This nucleus consisted mainly of small neurones and also of some medium-sized neurones. The neurones in this nucleus were well-preserved in both amyotrophic lateral sclerosis and in control subjects, and were microscopically recognisable as a distinct group (Fig. 5a, b).

Glial cells seemed to have increased somewhat in the grey matter of one of the cases of amyotrophic lateral sclerosis, but virtually no morphological abnormalities were present in any of the neurones within the nucleus. 


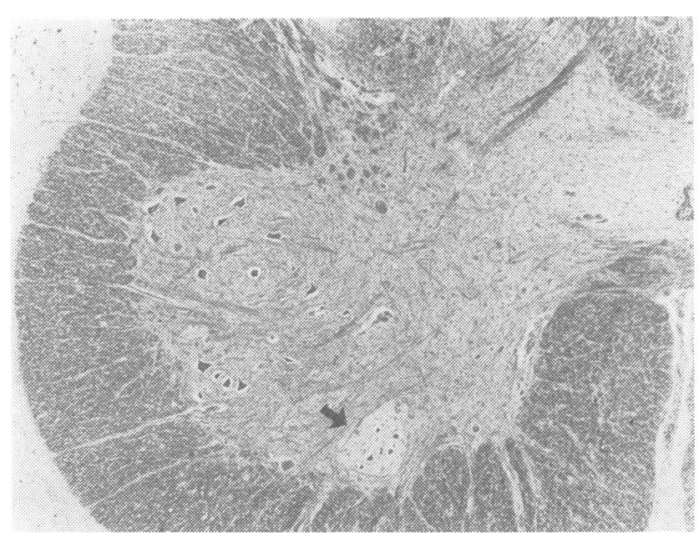

(a)

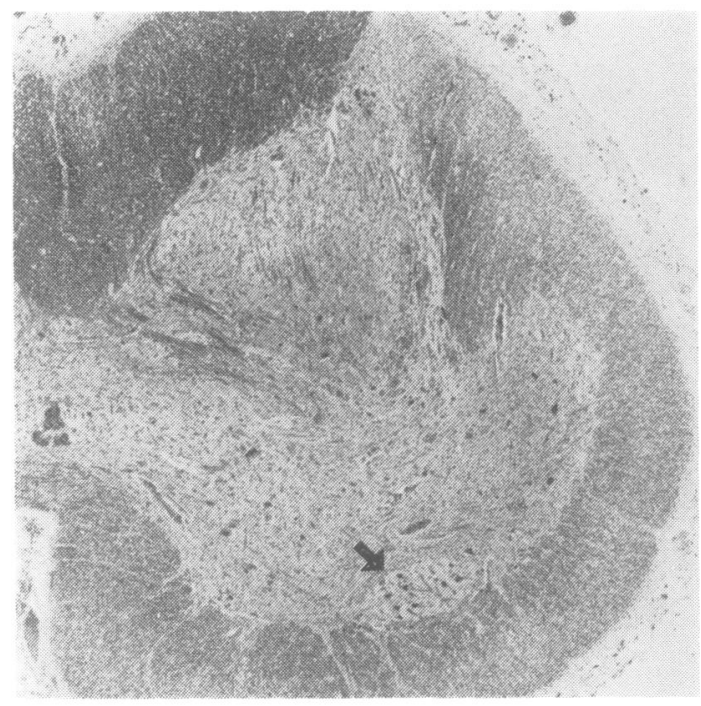

(b)

Fig. 4 Group $X$ (arrow) is sharply demarcated by the fine myelinated fibres. Klüver-Barrera stain.

(a) Normal. (b) Amyotrophic lateral sclerosis (case 5).

POSTERIOR HORNS OF THE SACRAL CORD

No abnormalities were observed in the nerve cells of posterior horns in amyotrophic lateral sclerosis. There were no differences from the normal controls.

\section{Discussion}

Since Charcot and Joffroy described amyotrophic lateral sclerosis in 1869 , a number of studies have been undertaken on this disease from various points of view. These have proved that atrophy of the muscles is secondary to the loss of neurones in the anterior horns of the spinal cord; bulbar palsy is an outcome

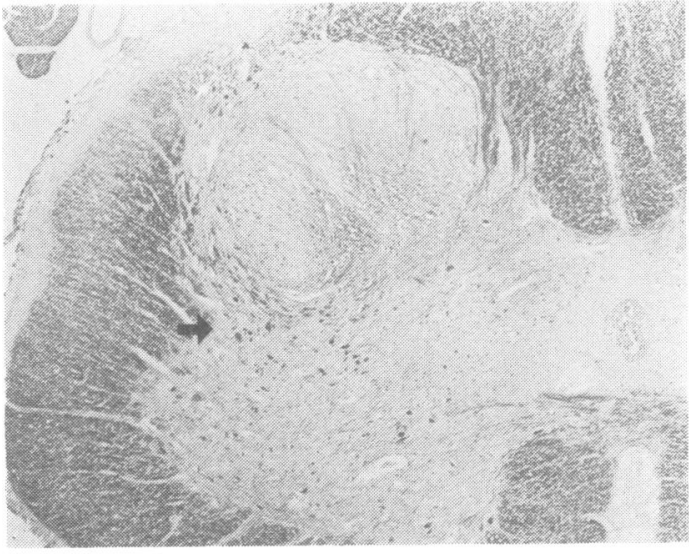

(a)

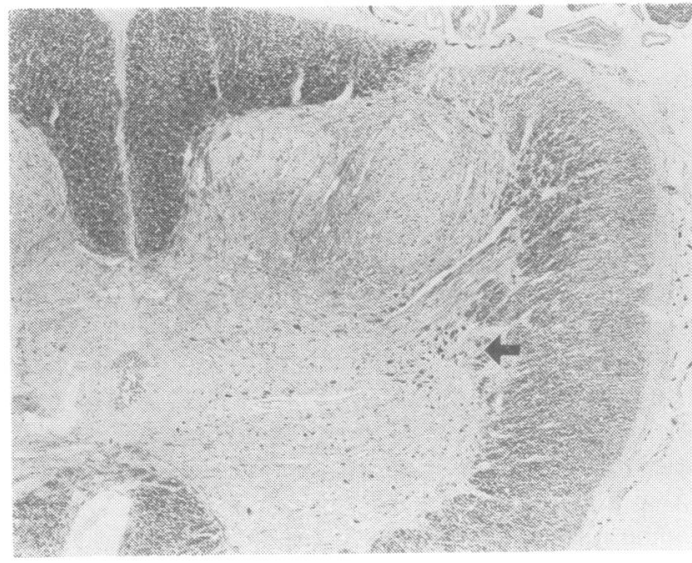

(b)

Fig. 5 Nucl. intermediolateralis (arrow) shows normal appearance, but the anterior horn cells have almost disappeared. Klüver-Barrera stain. (a) $S 3$ (amyotrophic sclerosis, case 3) (b) $S 4$ (amyotrophic lateral sclerosis, case 3).

of degeneration of the lower cranial motor neurones, and exaggeration of tendon reflexes is in proportion to degeneration of the pyramidal tracts. Thus, the correlation between the main clinical features and the pathological findings is considered to have been established, and to be a part of classical knowledge in neurology.

However, previous pathological research has failed to account for the fact that vesicorectal disturbance does not occur until the last stage of the disease. To maintain normal vesicorectal function, both internal and external sphincter muscles have to function properly. The innervation of the urinary bladder consists of sympathetic, parasympathetic, 
and somatic components. The efferent parasympathetic fibres, arising from the second to the fourth sacral segments of the spinal cord, innervate the detrusor muscle and the sphincter vesicae (internal sphincter). The sympathetic fibres are also distributed to the detrusor and the sphincter vesicae, but normal micturition is controlled exclusively by the parasympathetic nervous system. The sphincter urethrae (external sphincter), a somatic striated muscle, is innervated by the pudendal nerve (S2-4) (Warwick and Williams, 1973).

On the other hand, the internal anal sphincter receives its sympathetic innervation from the fifth lumbar segment and its parasympathetic innervation from the first, second, and third sacral segments. The external anal sphincter receives only somatic pudendal innervation (Schuster, 1968).

Okinaka (1932) pointed out that, in amyotrophic lateral sclerosis, the nerve cells of the autonomic nervous system in the intermediolateral column at the thoracic level, and in the intermediolateral nucleus at the sacral level, remain unaffected. On the other hand, the classical pathological investigations on the disease, such as those of Holmes (1909), Bertrand and van Bogaert (1925), and Marburg (1936), stated that the anterior horn cells of the sacral cord were as highly involved as those at the other levels of the spinal cord. In the recent reports by Lawyer and Netsky (1953), Brownell et al. (1970), and Castaigne et al. (1972), pathological findings of the sacral cord of amyotrophic lateral sclerosis were similar to the previous reports.

Cell groups which innervate various muscles in the lower limbs are known to be located in the anterior horns of the sacral cord. The motoneurones innervating the external sphincters of bladder and rectum supposedly exist somewhere at this level. However, there have been no detailed descriptions of the sacral cord in amyotrophic lateral sclerosis as described in this paper. Except for the second sacral segment, the findings in the present study are in complete agreement with the previous reports, and the changes in the anterior horn were equally marked.

In the anterior horns of the second sacral segment of amyotrophic lateral sclerosis, a group of nerve cells which is well-preserved and quite indistinguishable from those in the normal controls persisted. In crosssection, this group of nerve cells is located in the margin of the anterior horn between the ventrolateral and the ventromedial cell groups. Judging from the microsconic appearances, each of these neurones is a motor neurone. The next logical question concerns the anatomical and physiological significance of this cell group.

According to the literature on the cytoarchitecture of the spinal cord, Onuf (Onufrowicz) (1899) first pointed out that there was a particular cell group in the human sacral cord. He studied the cytoarchitecture of the human sacral cord in serial transverse sections, and found a special cell group in the anterior horn of the second sacral segment. He distinguished this cell group from the other cell groups of the anterior horn and named it group X. In the next year, 1900 , he published a more detailed paper on this cell group. He pointed out that nerve cells in this group were small in comparison with those in the anterolateral group of the more rostral segments; they were rather plump, and typically polygonal. According to his description, group $\mathrm{X}$ is a specific formation at the level of the second sacral segment, but might sometimes extend from the inferior part of the first sacral segment to the upper part of the third sacral segment. He made no reference to the staining method, but Nissl stain seems to have been employed, judging from the figures in his paper (Fig. 6). As he did not use other staining methods, various features of group $X$ remain uncertain. Few studies have been done since Onuf's description. Bertrand and van Bogaert (1923) commented on the extension of group X and the nature of the nerve cells of this group using Nissl stain. In a review of the anatomy of the spinal cord, Bok (1928) quoted Onuf's description, but he thought that group $\mathrm{X}$ probably corresponded with nucleus myoleioticus medialis.

Laruelle (1937) studied the cytoarchitecture of the spinal cord cut longitudinally and stained with silver impregnation and gave a full account of the characteristics of group X. According to his descriptions, this group extended from the most caudal part of the first sacral segment to the third sacral segment with the appearance of spun yarn, and consisted of two different types of nerve cells, a motoneurone type and an autonomic neurone type, with their axons directed toward the anterior roots. Ogawa (1951) studied this cell group with Pal-Weigert stain, and mentioned that it was well-demarcated and appeared somewhat bright with this stain.

The cell group in the anterior horn of the second sacral segment of cases of amyotrophic lateral sclerosis, then, completely coincides with Onuf's group $\mathrm{X}$ in its cross-sectional position, craniocaudal extension, and neuronal characteristics. As pointed out previously, this cell group stood out clearly from its surroundings which were demarcated from the fine myelinated fibres by Klüver-Barrera stain. These characteristics correspond closely to Ogawa's description, made mostly from myelin stained preparations (Fig. 7a, b).

What is the function of group X? Onuf (1900) at first supposed that the group, distinguished from other neuronal groups in the anterior horn by the smaller size of its cells, might be a centre for the 


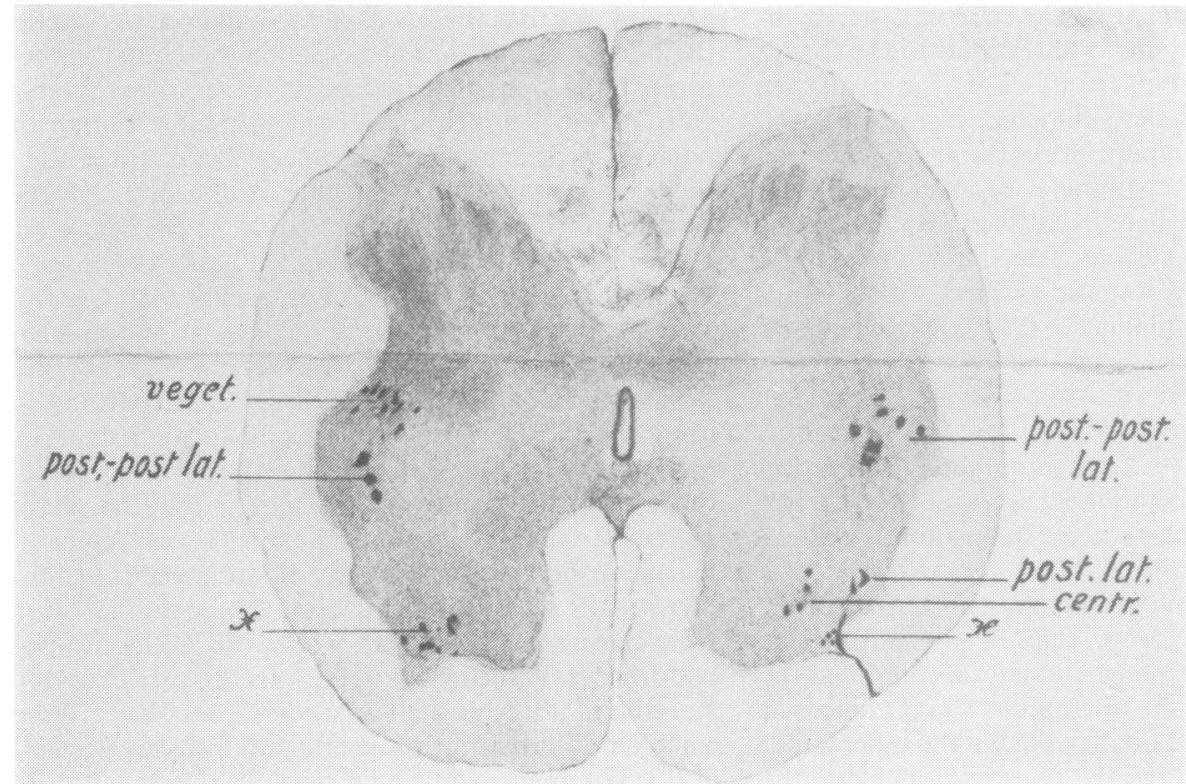

Fig. 6 Reproduced from Onuf (1900).

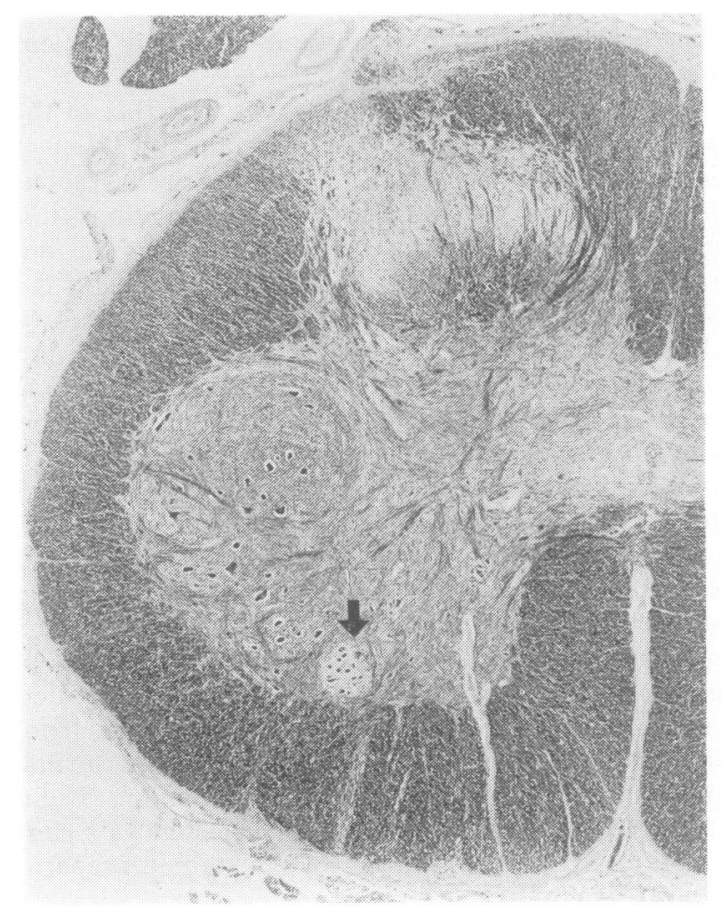

(a)

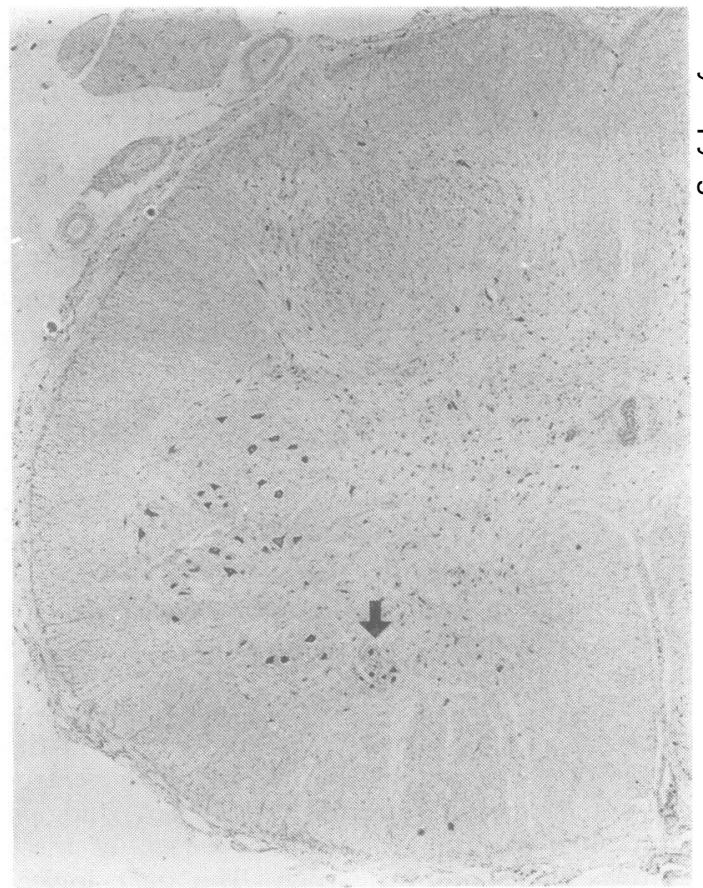

(b)

Fig. 7 Group X (arrow) stands out clearly from its surroundings with Klüver-Barrera stain, but this feature is not seen with Nissl stain. (a) Klüver-Barrera stain. (b) Nissl stain. 
vesical and rectal sphincters. But this was thought to contradict clinical experience at that time regarding the location of the sphincter centre. He finally concluded that group $X$ might have a certain special function on account of its circumscribed character. He speculated that it might be a centre for some of the striated muscles that coordinated the acts of erection and ejaculation, such as the ischiocavernosus or erector clitoridis, and the bulbocavernosus or sphincter vaginae muscles. On the probable function of this group, Laruelle (1937) pointed out three possibilities: (1) the centre for the striated muscles of pelvic organs; (2) the centre for parasympathetic fibres, and (3) the centre for coordination between striated and smooth muscles, which was required in complicated actions such as micturition, defaecation, and ejaculation. Of these possibilities, the centre for parasympathetic fibres does not seem possible because, in a previous study by Schnitzlein et al., (1963), the sacral parasympathetic nucleus was found to be confined within the intermediolateral region of the sacral cord. Recently, a new operation to restore the function of the paralysed bladder in paraplegics has been developed, by implantation of an electrode in the region near the first and second sacral segments. The residual function of the bladder was restored (Nashold et al., 1972). This seems significant in considering the anatomical distribution of the nerves which innervate the sphincter muscles in humans. Furthermore, electromyography of the external anal sphincter muscle in cases with amyotrophic lateral sclerosis revealed that its motor unit action potential was completely normal (Sakuta et al., 1976).

The physiological and anatomical significance of group $\mathrm{X}$ cells in the sacral cord remains to be elucidated by further studies. However, the facts that the group $\mathrm{X}$ is well-preserved and vesicorectal functions remain intact until the late stage of amyotrophic lateral sclerosis strongly suggest that the motoneurones in Onuf's cell group X of the second sacral segment are those innervating the external sphincters of the anus and bladder.

We would particularly like to thank Dr P. W. Nathan and Dr S. M. Chou for their excellent advice and gracious help in preparing this manuscript.

\section{References}

Bertrand, I., and van Bogaert, L. (1923). Étude de cytoarchitectonie médullaire. Revue neurologique, 30, 177-209, and 312-334.

Bertrand, I., and van Bogaert, L. (1925). Rapport sur la sclérose latérale amyotrophique (anatomie pathologique). Revue neurologique, 32, 779-806.

Bok, S. T. (1928). Das Rückenmark. In: Handbuch der mikroskopischen Anatomie des Menschen. Bd. 4, pp.478578. Edited by W. von Möllendorf. Springer: Berlin.
Brownell, B., Oppenheimer, D. R., and Hughes, J. T. (1970). The central nervous system in motor neurone diseases. Journal of Neurology, Neurosurgery, and Psychiatry, 33, 338-357.

Castaigne, P., Lhermitte, F., Cambier, J., Escourolle, R., and Le Bigot, P. (1972). Étude neuropathologique de 61 observations de sclérose latérale amyotrophique. Discussion nosologique. Revue neurologique, 127, 401-414.

Charcot, J.-M., and Joffroy, A. (1869). Deux cas d'atrophie musculaire progressive avec lesion de la substance grise et faisceaux antérolatéraux de la moelle épinière. Archives de Physiologie Normale et Pathologique, 2, 354-367, 629-649, and 744-760.

Holmes, G. (1909). The pathology of amyotrophic lateral sclerosis. Review of Neurology and Psychiatry (Edinburgh), 8, 693-725.

Laruelle, L. (1937). La structure de la moelle epinère en coupes longitudinales. Revue neurologique, 67, 695-725.

Lawyer, T., Jr., and Netsky, M. G. (1953). Amyotrophic lateral sclerosis. A clinicoanatomic study of fifty-three cases. Archives of Neurology and Psychiatry (Chicago), 69, 171-192.

Marburg, O. (1936). Die chronisch progressiven nuclearen Amyotrophien. In: Handbuch der Neurologie. Bd. 16, Spezielle Neurologie 8, pp. 524-605. Edited by $O$. Bumke, and O. Foerster. Springer: Berlin.

Nashold, B. S., Jr., Friedman, H., Glenn, J. F., Grimes, J. H., Barry, W. F., and Avery, R. (1972). Electromicturition in paraplegia. Implantation of a spinal neuroprosthesis. Archives of Surgery (Chicago), 104, 195-202.

Ogawa, T. (1951). Anatomy of Brain (In Japanese). p. 21. Nanzando: Tokyo.

Okinaka, S. (1932). Histologische Studien über die extrapyramidalen Bahnen. Über die periphere Fortsetzung der extrapyramidalen Bahnen. Zeitschrift der TokioMedicinischen Gesellschaft (Tokyo), 46, 1006-1054.

Onuf (Onufrowicz), B. (1899). Notes on the arrangement and function of the cell groups in the sacral region of the spinal cord. Journal of Nervous and Mental Disease, 26, $498-504$.

Onuf (Onufrowicz), B. (1900). On the arrangement and function of the cell groups of the sacral region of the spinal cord in man. Archives of Neurology and Psychopathology, 3, 387-411.

Sakuta, M., Nakanishi, T., and Toyokura, Y. (1976). An electromyographic study of the external sphincter muscle of anus in amyotrophic lateral sclerosis. Neurological Medicine (Tokyo), 4, 153-156.

Schnitzlein, H. N., Hoffman, H. H., Hamlett, D. M., and Howell, E. M. (1963). A study of the sacral parasympathetic nucleus. Journal of Comparative Neurology, 120, 477-493.

Schuster, M. M. (1968). Motor action of rectum and anal sphincters in continence and defecation. In: Handbook of Physiology, Section 6: Alimentary canal, Volume 4. Motility. pp. 2121-2140. Section editor C. F. Code. American Physiological Society: Washington.

Warwick, R. and Williams, P. L. (1973). Splanchnology 8. In: Gray's Anatomy, 35th edition. p. 1333. Longman: London. 